\title{
The long distance transport of airborne Ambrosia pollen to the UK and the Netherlands from Central and south Europe
}

\author{
Letty A. de Weger ${ }^{1}$ - Catherine H. Pashley ${ }^{2}$ - Branko Šikoparija ${ }^{3,4}$ • Carsten A. Skjøth ${ }^{5}$. \\ Idalia Kasprzyk $^{6}$ • Lukasz Grewling ${ }^{7}$ - Michel Thibaudon ${ }^{8}$ - Donat Magyar ${ }^{9}$. \\ Matt Smith $^{7}$
}

Received: 30 July 2015 / Revised: 7 April 2016 / Accepted: 9 April 2016/Published online: 27 April 2016

(C) The Author(s) 2016. This article is published with open access at Springerlink.com

\begin{abstract}
The invasive alien species Ambrosia artemisiifolia (common or short ragweed) is increasing its range in Europe. In the UK and the Netherlands, airborne concentrations of Ambrosia pollen are usually low. However, more than 30 Ambrosia pollen grains per cubic metre of air (above the level capable to trigger allergic symptoms) were recorded in Leicester (UK) and Leiden (NL) on 4 and 5 September 2014. The aims of this study were to determine whether the highly allergenic Ambrosia pollen recorded during the episode could be the result of long distance transport, to identify the potential sources of these pollen grains and to describe the conditions that facilitated this possible long distance transport. Airborne Ambrosia pollen data were collected at 10 sites in Europe. Back trajectory and atmospheric dispersion calculations were performed using HYSPLIT_4. Back trajectories calculated at Leicester and Leiden show that higher altitude air masses $(1500 \mathrm{~m})$ originated from source areas on the
\end{abstract}

Electronic supplementary material The online version of this article (doi:10.1007/s00484-016-1170-7) contains supplementary material, which is available to authorized users.

Letty A. de Weger

1.a.de_weger@lumc.nl

1 Department of Pulmonology, Leiden University Medical Centre, PO Box 9600, 2300RC Leiden, The Netherlands

2 Institute for Lung Health, Department of Infection, Immunity and Inflammation, University of Leicester, Leicester, UK

3 Laboratory for Palynology, Department of Biology and Ecology, Faculty of Sciences, University of Novi Sad, Novi Sad, Serbia

4 BioSense Institute, Research Institute for Information Technologies in Biosystems, University of Novi Sad, Novi Sad, Serbia
Pannonian Plain and Ukraine. During the episode, air masses veered to the west and passed over the Rhône Valley. Dispersion calculations showed that the atmospheric conditions were suitable for Ambrosia pollen released from the Pannonian Plain and the Rhône Valley to reach the higher levels and enter the airstream moving to northwest Europe where they were deposited at ground level and recorded by monitoring sites. The study indicates that the Ambrosia pollen grains recorded during the episode in Leicester and Leiden were probably not produced by local sources but transported long distances from potential source regions in east Europe, i.e. the Pannonian Plain and Ukraine, as well as the Rhône Valley in France.

Keywords Ambrosia $\cdot$ Long distance transport · Back trajectory analysis $\cdot$ Atmospheric movement $\cdot$ Pannonian Plain

5 National Pollen and Aerobiology Research Unit, Institute of Science and the Environment, University of Worcester, Henwick Grove, Worcester, UK

6 Department of Environmental Biology, University of Rzeszów, Rzeszów, Poland

7 Laboratory of Aeropalynology, Faculty of Biology, Adam Mickiewicz University, Poznań, Poland

8 Reseau National de Surveillance Aerobiologique (RNSA), Brussieu, France

9 Department of Aerobiology and Air Hygiene, National Public Health Center, Budapest, Hungary 


\section{Introduction}

Allergic sensitization can result in disorders of the airways such as allergic rhinitis, conjunctivitis and allergic asthma (Zheng et al. 2011). Pollen grains from wind-pollinating (anemophilous) plants are often the causative agents of sensitization (Bousquet et al. 2007). Pollen from Ambrosia plants is one of the most relevant allergens in the USA (Oswalt and Marshall 2008) and is becoming an increasing problem in Europe. Ambrosia was accidentally introduced into Europe at the end of the nineteenth century. Since then, the plant has been steadily conquering Europe causing harm to agriculture and to public health (Smith et al. 2013). The most infested areas of Europe are currently the Rhône Valley in France, northern Italy, the Pannonian Plain, and large areas in Ukraine and western Russia (Skjøth et al. 2010; Smith et al. 2013; Thibaudon et al. 2014; Prank et al. 2013; Podberezko et al. 2013; Reznik 2009). Concomitantly, with the increase in plant abundance, there has been an increase in the number of patients sensitized to Ambrosia: $\sim 60 \%$ in Hungary (Makra et al. 2004); 47 \% in France, mainly the Rhône Valley (Thibaudon et al. 2010); and an increase from $24 \%$ in 1989 to $70 \%$ in 2008 was witnessed in northern Italy (Tosi et al. 2011). In countries like Spain and the UK, the Ambrosia sensitization rate is still low (Bousquet et al. 2007), corresponding with the scarcity of the plant in these areas.

Ambrosia seeds are constantly being introduced into Europe via imported grain and animal fodder resulting in areas around entry points, such as harbours or airports, being heavily infested by Ambrosia. Recent studies suggest a progress of the plant into Germany (e.g. Berlin, (Starfinger 2008)) and to a lesser extent the Netherlands (de Weger et al. 2009; Smith et al. 2013). In the Netherlands, most of the observations are of single plants or very small populations, often in private gardens, and probably originating from bird seed. However, recent analysis showed that there has been a small increase in the number of larger populations ( $>50$ plants) in public spaces (Beringen et al. 2014; Smith et al. 2013). In the UK, Ambrosia is primarily an alien invasive plant of open, ruderal habitats (Essl et al. 2015). Ambrosia plants require long-lasting autumns and a late first-frost for their seeds to mature, which limits their northward distribution in Europe. Recent studies based upon climate change prediction models have suggested that habitat suitable for Ambrosia range expansion will extend further north and east such that it will become established in Scandinavian countries and Britain by 2050 (Hamaoui-Laguel et al. 2015; Storkey et al. 2014).

In regions that scarcely record any Ambrosia pollen, occasional peaks in atmospheric Ambrosia pollen concentrations are likely to be caused by long distance transport (LDT) from sources hundreds of kilometres away (e.g. (Belmonte et al. 2000; Fernández-Llamazares et al. 2012; Makra et al. 2010; Cecchi et al. 2006; Smith et al. 2013)). Studies in Poland using back trajectory analysis showed that peaks in airborne Ambrosia pollen recorded during the night and early in the morning were most likely brought by air masses loaded with pollen from the southern areas, like the Czech Republic, Slovakia and Hungary (Smith et al. 2008; Stach et al. 2007). Similarly, Kasprzyk et al. (2011) showed that Ukraine may be a source area of Ambrosia pollen for Poland.

Airborne concentrations of Ambrosia pollen are usually low in the UK and the Netherlands, generally not exceeding 10 pollen grains per year (de Weger et al. 2009; Pashley et al. 2015). The climatic conditions in these countries are not currently favourable for fulfilling the full life cycle of Ambrosia. The late flowering of the plant combined with the early dates of the first frosts in autumn prevents the Ambrosia seeds from ripening. However, future climate scenarios for the Netherlands (Klein Tank et al., 2014) and for Europe (Storkey et al. 2014) have suggested that Ambrosia could spread and persistent as far north as central England by the year 2050, with areas where Ambrosia populations are currently classed as casual becoming established. It is important to prevent the plant from becoming established in new regions since examples from other European countries have shown the dramatic increase in Ambrosia sensitization once this occurs. It is therefore imperative to routinely monitor for airborne Ambrosia pollen as this can be an early warning of invasion by the plant. Such routine monitoring revealed that, at the beginning of September 2014, more than 30 Ambrosia pollen grains per cubic metre of air were recorded in Leicester (UK) and Leiden (Netherlands), where there are no known local stands of Ambrosia plants. The aims of this study were to (1) determine whether this episode could be the result of LDT, since local sources are not known to be present; (2) identify the potential sources of these pollen grains; (3) try to describe the conditions that facilitated this possible episode of LDT that resulted in unusually high atmospheric concentrations of Ambrosia pollen.

\section{Materials and methods}

\section{Pollen data}

Ambrosia pollen data were collected at 10 sites in Europe (Fig. 1) by volumetric spore traps of the Hirst design (Hirst 1952). Daily average and bi-hourly Ambrosia pollen concentrations are expressed as pollen grains per cubic metre of air $\left(\mathrm{P} \mathrm{m}^{-3}\right)$.

\section{Meteorological data}

The overall synoptic weather situation was investigated using analysed weather maps from the UK Met Office, as well as reanalysed meteorological data and meteorological 


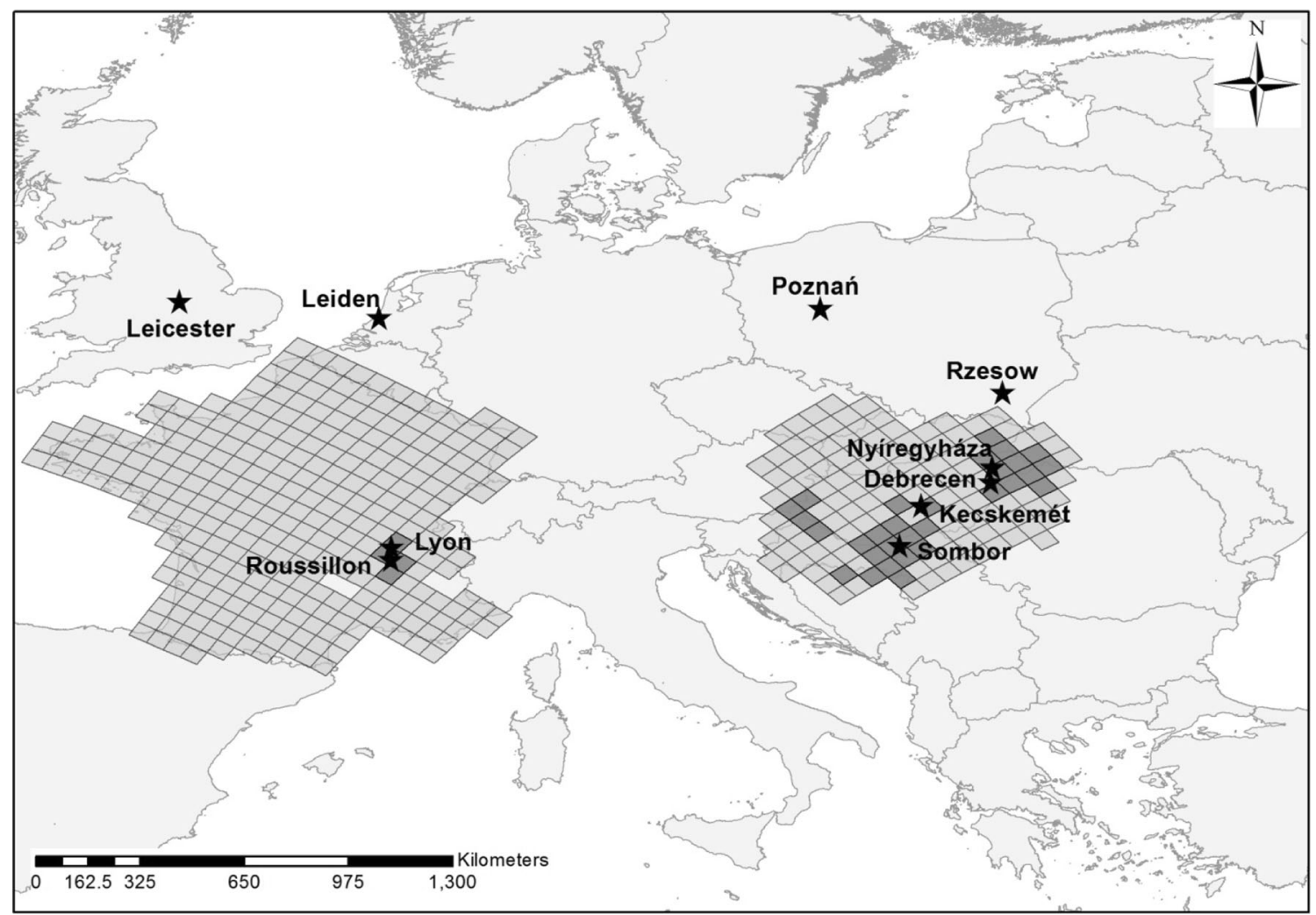

Fig. 1 Distribution of the aerobiological monitoring stations used in this study and Ambrosia pollen source inventories. Dark grey indicates grid cells entered into the dispersion model, corresponding to the areas with the highest Ambrosia plant infestation according to the inventories by Skjøth et al. (2010) and Thibaudon et al. (2014)

trajectories examined in this study showed little variation with respect to transport path (Stach et al. 2007).

Input meteorological data for 1-7 September 2014 came from the Global Data Analysis System (GDAS) dataset provided by the NCEP that covers the period 2006 to present in the form of a $1^{\circ}$ latitude-longitude grid (https://ready.arl.noaa. gov/gdas1.php).

\section{Dispersion modelling}

Particle dispersion calculations were carried out with the HYSPLIT_ 4 model in order to determine whether atmospheric conditions during the studied episode would have allowed Ambrosia pollen to reach high altitude air masses after release in the source areas and to settle down in Leiden and Leicester following atmospheric transport.

In order to verify whether airborne Ambrosia pollen released in the source area could reach the altitudinal range of back trajectories arriving at Leiden, the model was set to release 2500 particles of $20 \mu \mathrm{m}$ at $15 \mathrm{~m}$ above the ground each hour from 6 to $12 \mathrm{~h}$, which corresponds to the most intensive period of Ambrosia pollen release (Barnes et al. 2001; Martin et al. 2010). Sedimentation processes are accounted for in the model by setting the settling velocity of the particles to $0.0156 \mathrm{~m} / \mathrm{s}$ which corresponds to the settling velocity of transport path of the individual trajectories. All calculated 
Ambrosia artemisiifolia pollen grains (Raynor et al. 1970) and applying the conversion module that deposits each particle rather than reduce their mass.

The starting locations for the particles released into the dispersion model were previously identified as being the most important source areas for Ambrosia pollen on the Pannonian Plain (Skjøth et al. 2010) and France (Thibaudon et al. 2014) (Fig. 1). These source areas had been identified by the use of detailed knowledge of Ambrosia ecology, land cover information and spatial variations in the annual sum of atmospheric Ambrosia pollen concentrations.

Simulations of particle deposition using the HYSPLIT_ 4 were conducted again in order to determine whether Ambrosia pollen travelling at the height of air masses (as described by back trajectories) could settle out from the atmosphere to reach ground level monitoring sites. The dispersion model was set to run so that the released particles arrived at Leicester and Leiden at 12 $14 \mathrm{~h}$ on 5 September, which was the time when the highest Ambrosia pollen concentrations were recorded (Table 1). The emission points were selected based on the results of trajectory analysis (9 points for each trajectory in the cluster). Particles were released at an altitude of $\sim 1500 \mathrm{~m}$ in the path of the air masses travelling to Leicester (Suppl. Table 1) and Leiden (Suppl. Table 2). The model was set to release 500 particles per hour for $8 \mathrm{~h}$ (until the end of the period when the highest bi-hourly Ambrosia pollen concentrations were recorded). The total amount of released particles corresponds to approximately $20 \%$ of the pollen $\left(19,316 \mathrm{P} \mathrm{m}^{-3}\right)$ that reached the altitudinal range of air masses that passed over the Pannonian Plain on the way to Leiden.

\section{Results and discussion}

Unusually high daily average concentrations of airborne Ambrosia pollen, in excess of $30 \mathrm{P} \mathrm{m}^{-3}$, were recorded in Leicester (4-5 Sept 2014) and Leiden (3-5 Sept 2014) (Suppl. Figure 1 and Suppl. Table 3). Bi-hourly concentrations of Ambrosia pollen began to peak during the night and early morning and continued into the following day in both cities. These diurnal patterns suggested that the pollen grains did not originate from local sources, since studies have shown that Ambrosia pollen from local plants is usually recorded in the air from about 6.30 am to around midday (Ogden et al. 1969). Furthermore, the geographical scope of the episode, recorded in both Leicester and Leiden, suggests that this was not a localized phenomenon caused by emission from local populations (Sommer et al. 2015).

Back trajectory analyses show that air masses arriving at Leicester (Fig. 2) and Leiden (Fig. 3) on the 4 and 5 September came from an easterly direction. The analyses were
Table 1 The height of air masses arriving at Leiden after passing through the areas (Pannonian Plain or Rhône Valley) where the particle clouds were dispersed, and percentage of particles calculated to be present at each trajectory height range

\begin{tabular}{|c|c|c|c|c|}
\hline \multirow[b]{2}{*}{$\begin{array}{l}\text { Time at which } \\
\text { trajectories } \\
\text { arrived in } \\
\text { Leiden }\end{array}$} & \multicolumn{2}{|c|}{ Pannonian Plain } & \multicolumn{2}{|c|}{ Rhône Valley } \\
\hline & $\begin{array}{l}\text { Trajectory } \\
\text { height }(m)\end{array}$ & $\begin{array}{l}\% \text { of particles } \\
\text { dispersed in } \\
\text { trajectory } \\
\text { height }\end{array}$ & $\begin{array}{l}\text { Trajectory } \\
\text { height }(\mathrm{m})\end{array}$ & $\begin{array}{l}\% \text { of particles } \\
\text { dispersed in } \\
\text { trajectory } \\
\text { height }\end{array}$ \\
\hline $\begin{array}{l}\text { 4th September } \\
02: 00^{\mathrm{a}}\end{array}$ & - & - & - & - \\
\hline $\begin{array}{l}\text { 4th September } \\
\text { 04:00 }\end{array}$ & $\begin{array}{l}1233.9- \\
1965.0\end{array}$ & 15.3 & - & - \\
\hline $\begin{array}{l}\text { 4th September } \\
\text { 06:00 }\end{array}$ & $\begin{array}{r}1211.6- \\
1744.2\end{array}$ & 13.4 & - & - \\
\hline $\begin{array}{l}\text { 4th September } \\
\text { 08:00 }\end{array}$ & $\begin{array}{c}1097.9- \\
1762.5\end{array}$ & 18.1 & - & - \\
\hline $\begin{array}{l}\text { 4th September } \\
10: 00\end{array}$ & $\begin{array}{r}1332.1- \\
1975.3\end{array}$ & 12.2 & - & - \\
\hline $\begin{array}{l}\text { 4th September } \\
12: 00\end{array}$ & $\begin{array}{c}1164.3- \\
2236.9\end{array}$ & 19.7 & - & - \\
\hline $\begin{array}{l}\text { 4th September } \\
14: 00\end{array}$ & $\begin{array}{r}1114.9- \\
2295.2\end{array}$ & 22.0 & - & - \\
\hline $\begin{array}{l}\text { 4th September } \\
16: 00\end{array}$ & $\begin{array}{r}1018.3- \\
2391.5\end{array}$ & 26.4 & - & - \\
\hline $\begin{array}{l}\text { 4th September } \\
18: 00\end{array}$ & $\begin{array}{l}1112.0- \\
2190.2\end{array}$ & 21.6 & - & - \\
\hline $\begin{array}{l}\text { 4th September } \\
20: 00\end{array}$ & $\begin{array}{c}1190.9- \\
1924.7\end{array}$ & 16.4 & - & - \\
\hline $\begin{array}{l}\text { 4th September } \\
22: 00\end{array}$ & $\begin{array}{r}1212.9- \\
1945.8\end{array}$ & 15.9 & - & - \\
\hline $\begin{array}{l}\text { 5th September } \\
00: 00\end{array}$ & $\begin{array}{l}889.0- \\
1834.3\end{array}$ & 28.7 & - & - \\
\hline $\begin{array}{l}\text { 5th September } \\
\text { 02:00 }\end{array}$ & $\begin{array}{l}785.6- \\
2110.6\end{array}$ & 37.2 & - & - \\
\hline $\begin{array}{l}\text { 5th September } \\
\text { 04:00 }\end{array}$ & $\begin{array}{l}744.6- \\
2300.4\end{array}$ & 40.5 & - & - \\
\hline $\begin{array}{l}\text { 5th September } \\
06: 00\end{array}$ & $\begin{array}{l}685.0- \\
2322.7\end{array}$ & 44.3 & - & - \\
\hline $\begin{array}{l}\text { 5th September } \\
\text { 08:00 }\end{array}$ & $\begin{array}{l}519.7- \\
2234.8\end{array}$ & 55.6 & - & - \\
\hline $\begin{array}{l}\text { 5th September } \\
\text { 10:00 }\end{array}$ & $\begin{array}{r}454.9- \\
2348.1\end{array}$ & 60.6 & - & - \\
\hline $\begin{array}{l}\text { 5th September } \\
12: 00\end{array}$ & $\begin{array}{l}316.3- \\
2234.5\end{array}$ & 71.0 & $\begin{array}{r}1565.9- \\
1648.0\end{array}$ & 1.1 \\
\hline $\begin{array}{l}\text { 5th September } \\
14: 00\end{array}$ & $\begin{array}{l}337.5- \\
3624.7\end{array}$ & 70.4 & $\begin{array}{r}1573.0- \\
2482.1\end{array}$ & 2.3 \\
\hline $\begin{array}{l}\text { 5th September } \\
16: 00\end{array}$ & $\begin{array}{l}495.9- \\
3488.8\end{array}$ & 58.3 & $\begin{array}{r}1471.8- \\
2237.2\end{array}$ & 4.9 \\
\hline $\begin{array}{l}\text { 5th September } \\
18: 00\end{array}$ & $\begin{array}{l}593.7- \\
3570.2\end{array}$ & 51.5 & $\begin{array}{r}1554.2- \\
2316.7\end{array}$ & 2.6 \\
\hline $\begin{array}{l}\text { 5th September } \\
\text { 20:00 }\end{array}$ & $\begin{array}{l}689.2- \\
2981.8\end{array}$ & 44.8 & $\begin{array}{r}1583.2- \\
2438.2\end{array}$ & 2.1 \\
\hline $\begin{array}{l}\text { 5th September } \\
22: 00\end{array}$ & $\begin{array}{l}591.8- \\
2184.1\end{array}$ & 50.3 & $\begin{array}{c}1605.1- \\
2346.4\end{array}$ & 1.8 \\
\hline Average & $\begin{array}{l}854.2- \\
2348.5\end{array}$ & 36.1 & $\begin{array}{l}1558.9- \\
2244.8\end{array}$ & 2.5 \\
\hline
\end{tabular}

${ }^{\mathrm{a}}$ Trajectory did not pass over the areas where the particles were dispersed

performed for various altitudes, but only those air masses arriving at Leicester and Leiden at higher altitudes (e.g. 
Fig. 2 Clusters of 72-h backward trajectories calculated every $2 \mathrm{~h}$ 4th-5th September from Leicester at 500 (a) and $1500 \mathrm{~m}(\mathbf{b})$. The light grey colour indicates trajectories arriving when Ambrosia pollen was not recorded a

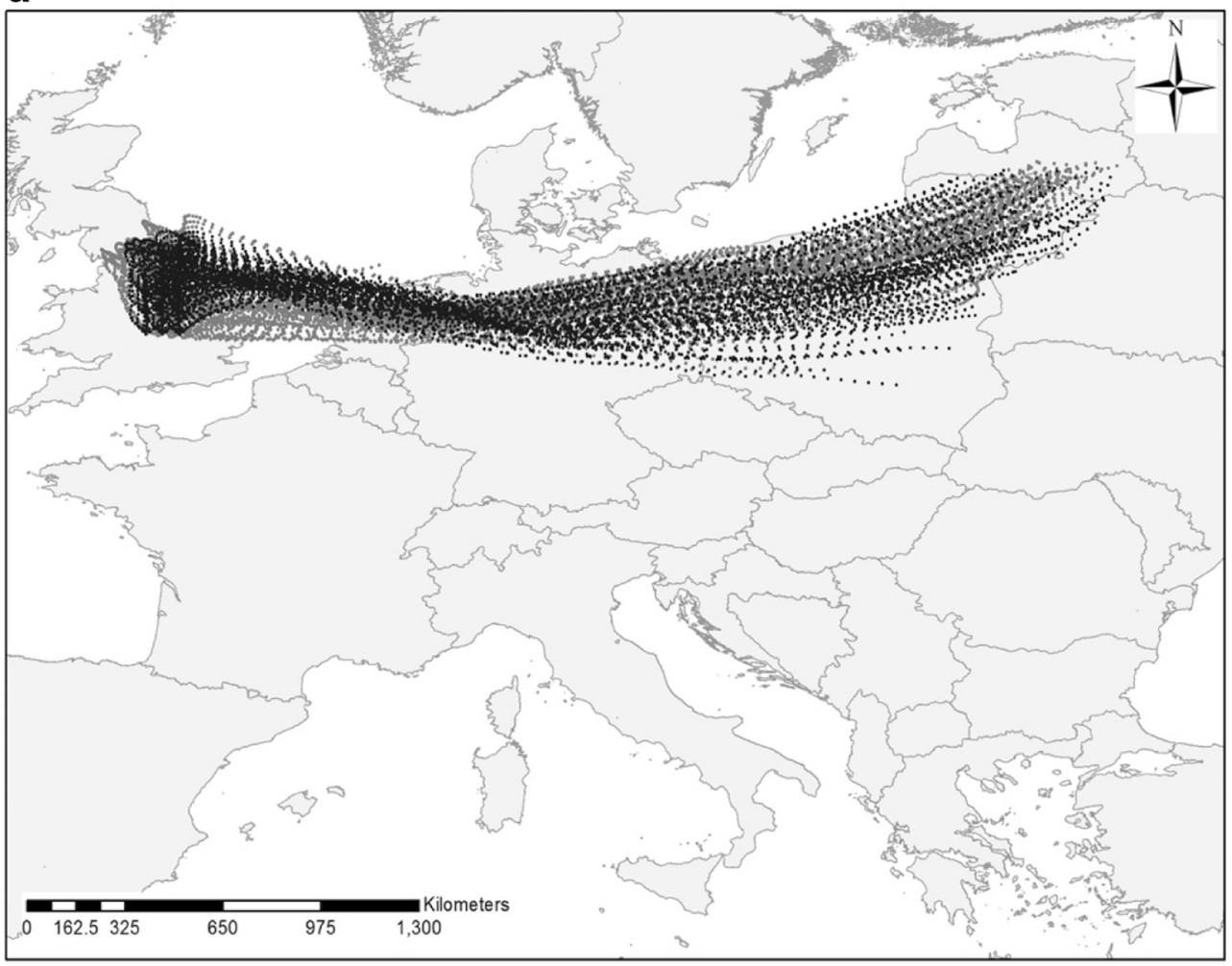

b

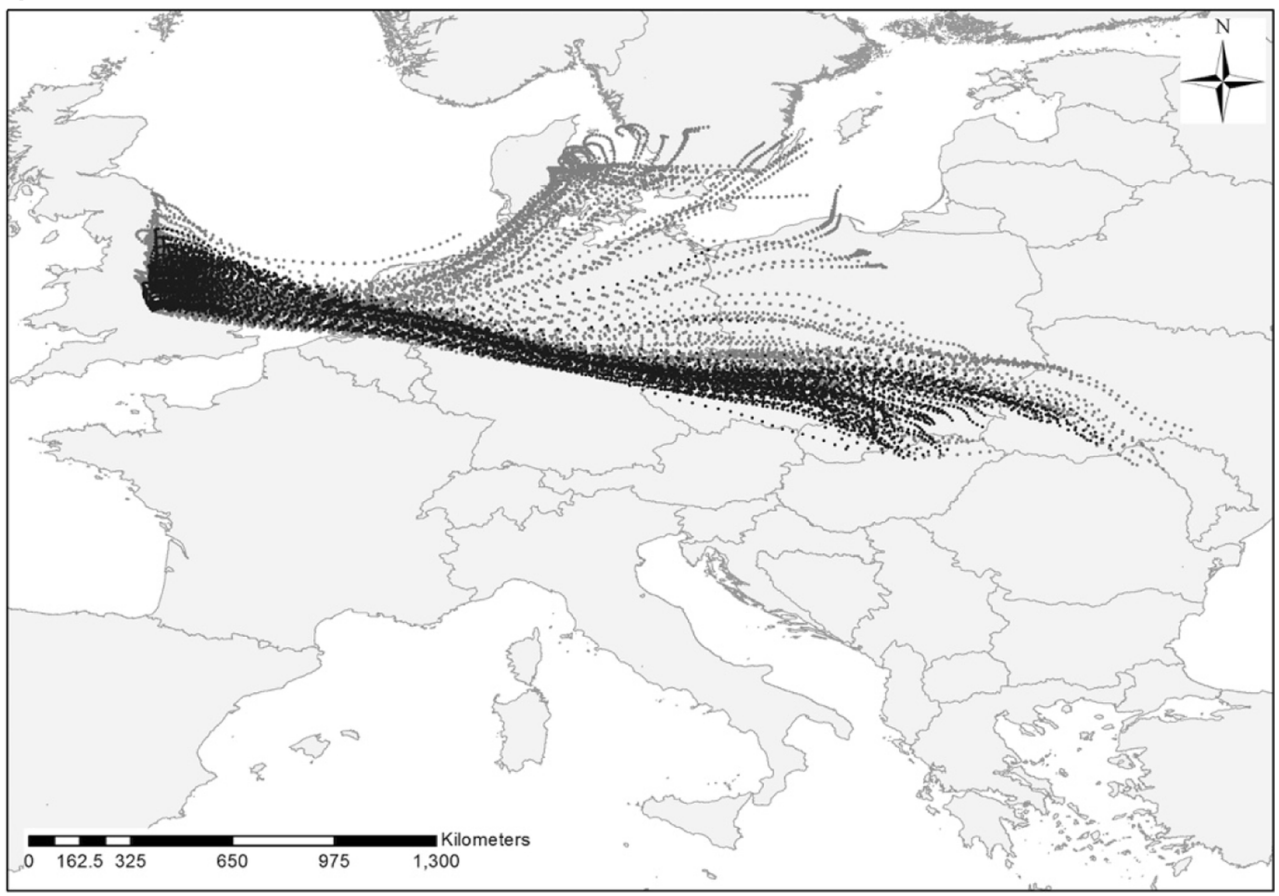

$1500 \mathrm{~m}$ above ground level (AGL)) passed over potential source areas on the Pannonian Plain (Skjøth et al. 2010) and Ukraine (Kasprzyk et al. 2011). Lower altitude air masses (e.g. $500 \mathrm{~m} \mathrm{AGL}$ ) tended to arrive from more northerly regions. It is interesting to note that the back trajectories calculated from
Leicester mainly pass over Ukraine, rather than the Pannonian Plain. Whereas, the higher altitude air masses arriving at Leiden spent a considerable amount of time over the Pannonian Plain. However, the air masses arriving at Leicester passed close to Leiden where it is likely that mixing 
Fig. 3 Clusters of 72-h backward trajectories calculated every $2 \mathrm{~h}$ 4th-5th September from Leiden at 500 (a) and $1500 \mathrm{~m}$ (b). The light grey colour indicates trajectories arriving when Ambrosia pollen was not recorded a

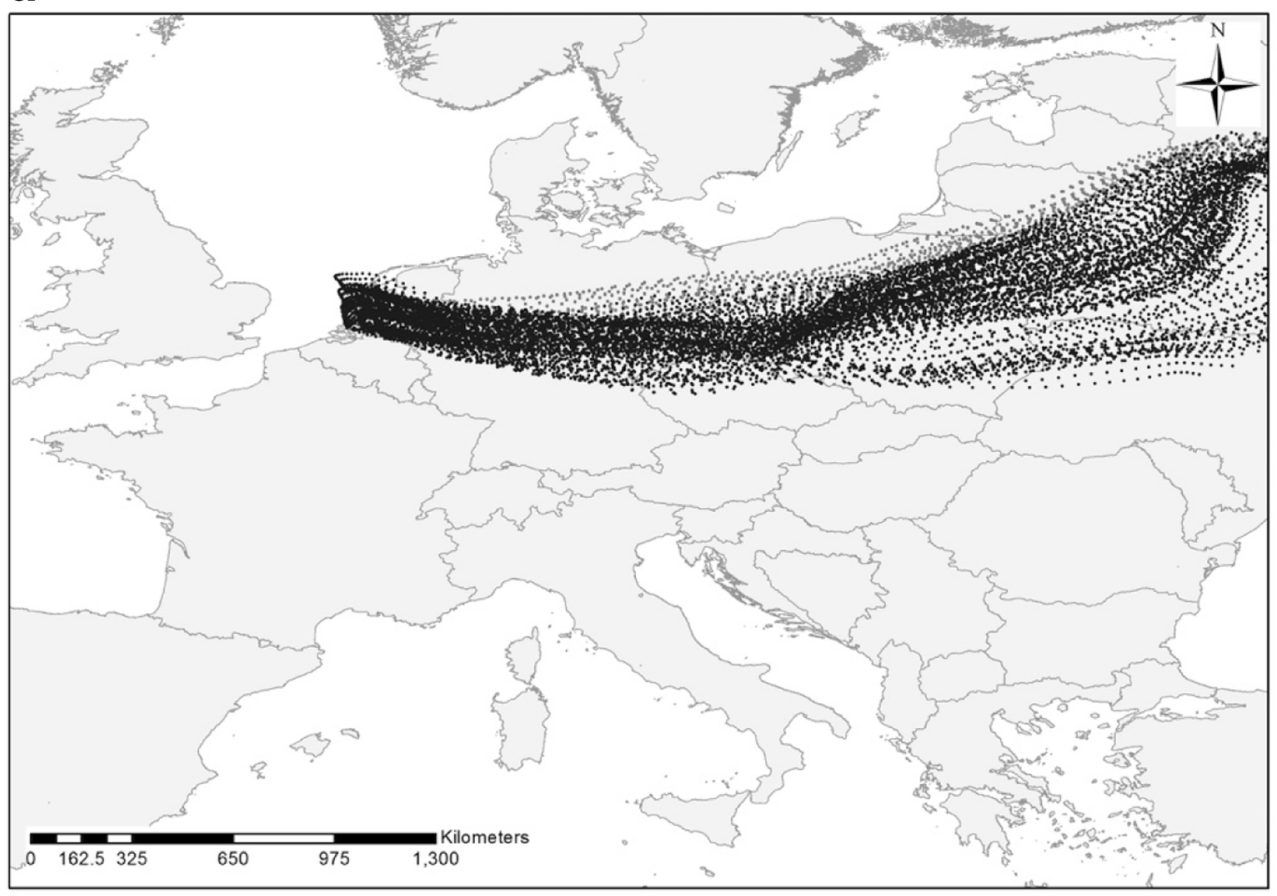

b

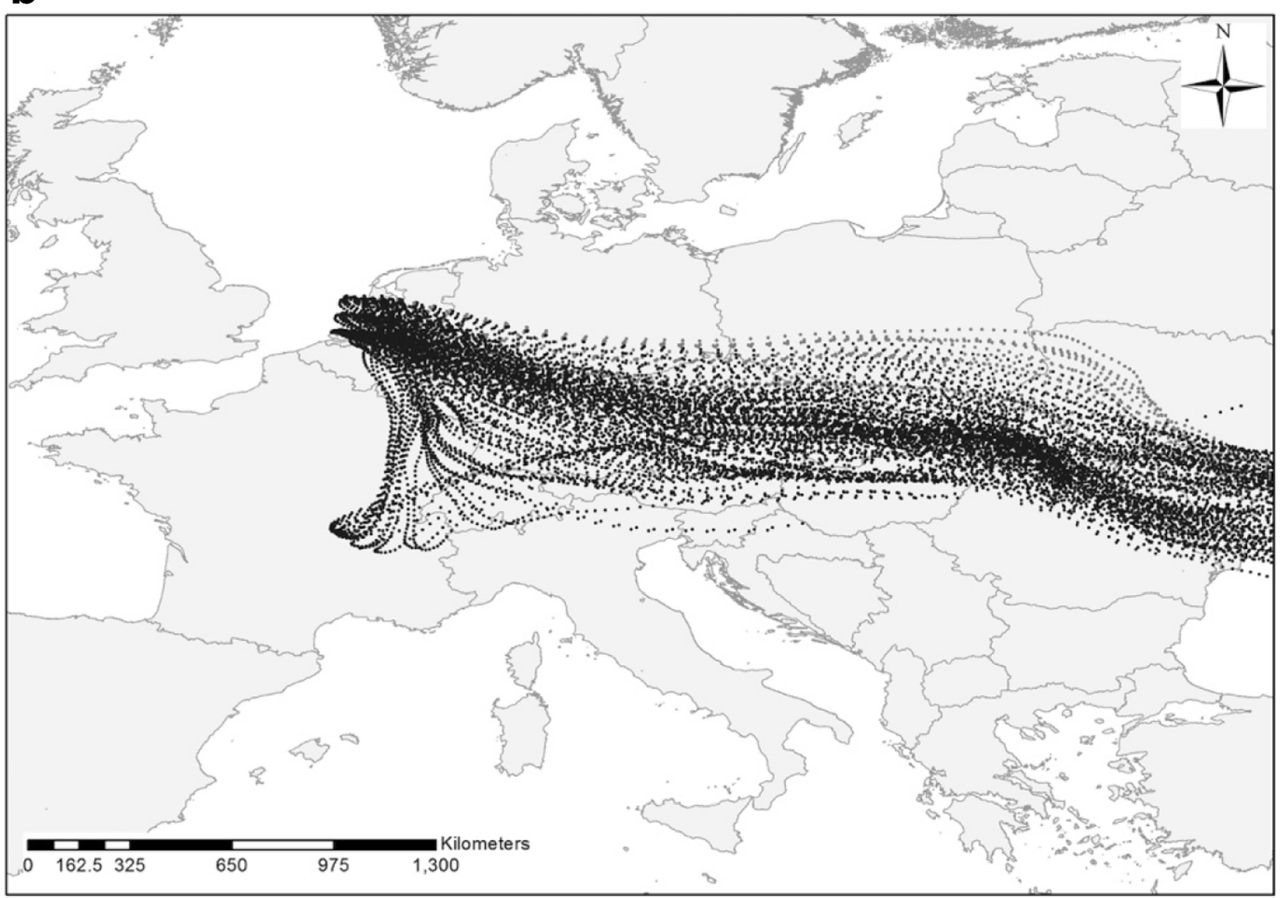

took place, indicating that both the Pannonian Plain and Ukraine were potential sources of airborne Ambrosia pollen at the two sites.

The idea that the Ambrosia pollen grains recorded in Leicester and Leiden were transported by high altitude air masses is supported by the fact that bi-hourly concentrations of Ambrosia pollen up to $377 \mathrm{P} \mathrm{m}^{-3}$ were recorded on the 2-3
September at Rzeszów, in Southeast Poland, which is located along the path taken by the high-level air masses travelling from Ukraine. On the other hand, very little airborne Ambrosia pollen (bi-hourly concentrations $\leq 5 \mathrm{P} \mathrm{m}^{-3}$ ) was recorded at this time in Poznań, in Western Poland, which lies on the path taken by the lower altitude air masses that approached from more northerly regions where notable 
sources of Ambrosia pollen have not been recorded (Suppl. Table 3, Figs. 2 and 3).

During the period 3-5 Sept. 2014, the synoptic situation was dominated by low-pressure systems (993-1012 hPa) residing over the Atlantic to the north of the British Isles and a high-pressure system $(1029-1031 \mathrm{hPa})$ situated over the Baltic and European Russia. An occlusion was positioned over Poland, Denmark and Germany, particularly during the 1-4 September. This occluded front generally ran from east to west and marked the route taken by the pollen. It also helped to direct the warm air masses from Ukraine and the Pannonian Plain up in to the atmosphere. The result was that several different air masses lay on top of one another (the definition of an occlusion) and caused the lower parts of the atmosphere to have a different origin compared to the upper part.

Pollen monitoring stations on the Pannonian Plain, i.e. Kecskemét, Debrecen, Nyíregyháza and Sombor, recorded bi-hourly concentrations of Ambrosia pollen in the range of 1000 to $4000 \mathrm{P} \mathrm{m}^{-3}$ during 1-6 September (Suppl. Table 3). It is likely that these pollen levels were of sufficient magnitude to allow large amounts of airborne Ambrosia pollen grains to be transported long distances (Šikoparija et al. 2013; Smith et al. 2008). In order to test the hypothesis that the Pannonian Plain could be a source of the Ambrosia pollen recorded in Leicester and Leiden, the HYSPLIT_4 dispersion model was run to determine whether the locally produced Ambrosia pollen could reach high enough altitudes to become entrained in high-level air flows moving towards northwest Europe. The calculations were made using the Ambrosia pollen source inventory produced by Skjøth et al. (2010) (Fig. 1). After release from heavily infested source areas on the Pannonian Plain on
2-3 September (6-12 h), an average of $36.1 \%$ of the particles remaining airborne reached between 316.3 and $3624.7 \mathrm{~m}$, which is the altitudinal range of back trajectories arriving at Leiden at the same time when the Ambrosia pollen was recorded (Table 1). Interestingly, only Ambrosia pollen grains released from sources in northern parts of the Pannonian Plain travelled northward and were able to enter the airstream travelling towards northwest Europe. Dispersion from sources located on southern parts of the Pannonian Plain tended to go south (Fig. 4). Unfortunately, a detailed inventory for Ambrosia pollen sources, as described for the Pannonian Plain (Skjøth et al. 2010) and France (Thibaudon et al. 2014), does not exist for Ukraine and so the analysis could not be repeated for this area.

Further investigation showed that towards the end of the episode, air masses calculated for $1500 \mathrm{~m}$, which arrived at Leiden between 12 and $22 \mathrm{~h}$ on 5 September 2014, veered south and approached from the direction of potential source regions in the Rhône Valley in France (Fig. 3b). At the pollen monitoring station of Roussillon, bi-hourly concentrations of airborne Ambrosia pollen between 642 and $1085 \mathrm{P} \mathrm{m}^{-3}$ were recorded during the morning of 4 September (Suppl. Table 3), which is the time period that the air masses dwelled around in the Rhône Valley before moving to Leiden.

The HYSPLIT_ 4 dispersion model was run again to determine whether the Ambrosia pollen produced in the most heavily infected areas in France (Thibaudon et al. 2014) could reach high altitudes. The particle cloud tended to go south on 3 September, but on 4 September, the particles reaching the higher levels went northward (Fig. 5). From particles remaining airborne after release, $2.5 \%$ reached between 1471.8 and

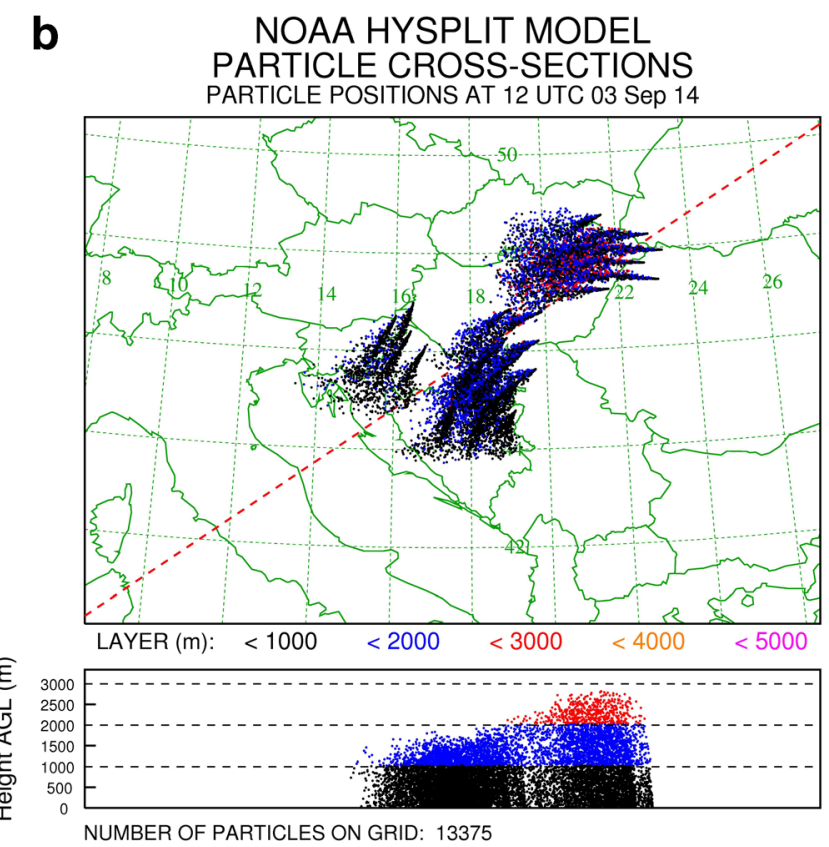

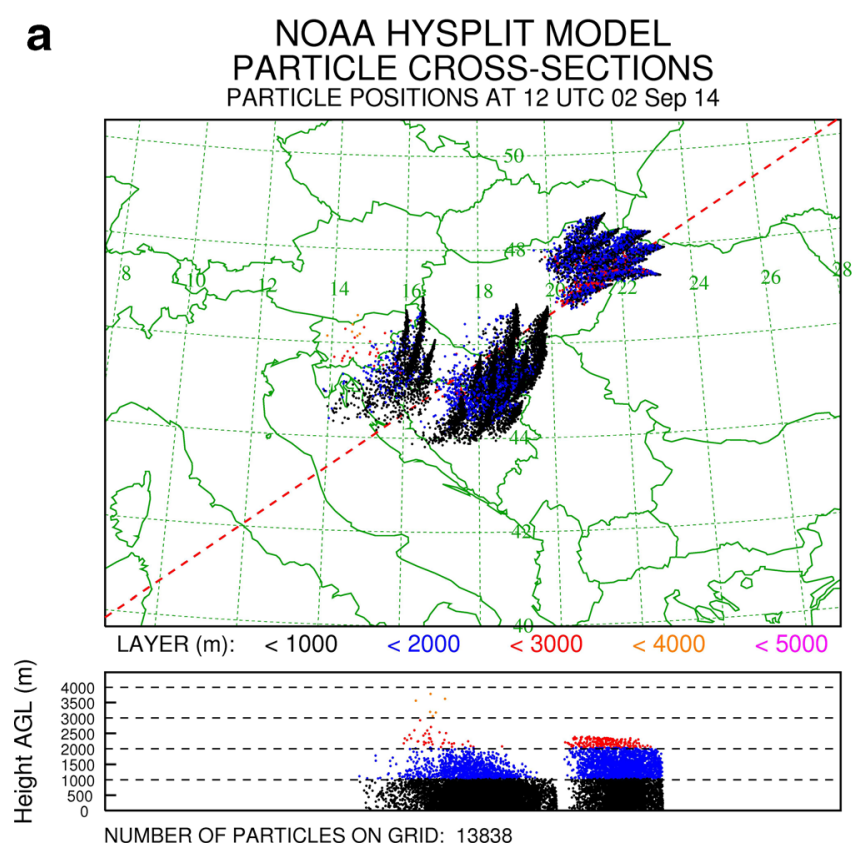

Fig. 4 The output of the HYSPLIT model calculations of the distribution of particles released from 6 to 12 am at the Pannonian Plain on 2 September (a) and 3 September $(\mathbf{b})$ 

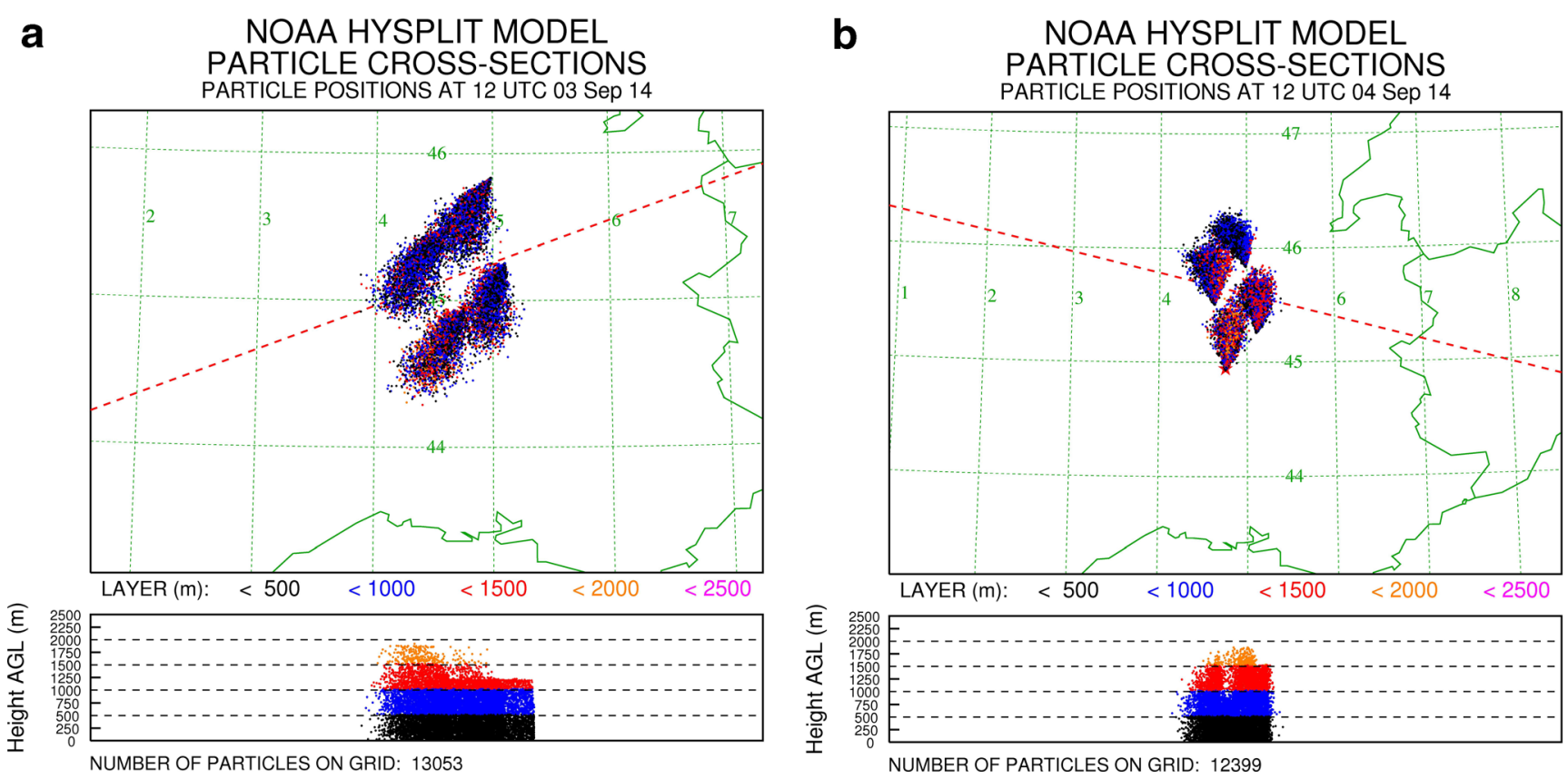

Fig. 5 The output of the HYSPLIT model calculations of the distribution of particles released from 6 to 12 am in the Rhône Valley in France on 3 September 2014 (a) and 4 September 2014 (b)

$2482.1 \mathrm{~m}$, which is the altitudinal range of back trajectories arriving at Leiden when the pollen grains were recorded in the trap (Table 1). Calculations of particle concentration distribution carried out on 3-4 September 2014 confirmed that Ambrosia pollen grains could have reached sufficiently high above the ground to enter into the airstream moving towards Leiden (Fig. 5, Table 1).

The Rhône Valley has previously been identified as a potential source of Ambrosia pollen for Catalonia (Belmonte et al. 2000) and Switzerland (Taramarcaz et al. 2005), but this is the first time that it has been identified as a potential source of Ambrosia pollen in northwest Europe. The Rhône Valley is a known centre of Ambrosia in Europe and is closer to Leiden and Leicester than the Pannonian Plain; however, this study has shown that under these conditions, only a fraction of pollen released from France reached northwest Europe. In addition, the uncertainty resulting from orographically forced meteorology within the Rhône Valley cannot be resolved with default HYSPLIT_4 input data. Focused studies in such a region require much more detailed data, e.g. from the Weather Research and Forecast model as described by HernandezCeballos et al. (2014). This suggests that the Pannonian Plain should still be considered to be the main source of the LTD Ambrosia pollen in Europe (Table 1).

HYSPLIT_4 simulations of particle deposition from the high altitude air masses, before they reached Leicester and Leiden, confirm that atmospheric conditions would have allowed for the deposition of airborne Ambrosia pollen to ground level in areas where surface pollen measurements took place (Fig. 6).
Several aspects of back trajectories are limited in respect to analysing air mass patterns. Earlier Ambrosia studies by Stach et al. (2007) and Šikoparija et al. (2009) used the Danish ACDEP model to calculate trajectories (Skjøth et al. 2002). This was a 2D trajectory model where the air masses followed the $\sigma$-level 0.925 wind vectors and $0.25^{\circ}$ meteorological input. This approach (e.g. terrain following coordinates or isobaric coordinates) is conceptually simpler, but it neglects the vertical wind component (Stohl 1998), which means that errors in the calculation of 2D trajectories can accumulate faster with transport distance than for 3D trajectories. Current practice is therefore to use $3 \mathrm{D}$ trajectories, most commonly in relation to Ambrosia by using the HYSPLIT model (e.g. Makra et al. (2010); Saulienè et al. (2011); Zemmer et al. (2012) and recently Sommer et al. (2015)). Spatial and temporal resolution in the input data is, however, also very important as demonstrated by Skjøth et al. (2002) and Hernandez-Ceballos et al. (2014). These studies suggest that coastal effects and complex terrain often affect the meteorology on scales that are relevant for pollen transport and more detailed input to HYSPLIT or ACDEP provided substantially better output data, thus improving the analytical results. The effect on spatial and temporal resolution, however, depends on the atmospheric physics during the pollen episodes. Simulations of large scale flows will generally be less affected by increased resolution. Conversely, simulations of frontal zones, convective zones and orographic force flow will be heavily affected (e.g. Hernandez-Ceballos et al. 2014). In our case, there are generally large scale flows over the Pannonian Plain towards Leiden, while the flow in the Rhône Valley could be affected by complex terrain. As such, 
a INTEGRATED PARTICLE CROSS-SECTIONS PARTICLE POSITIONS AT 14 UTC 05 Sep 14

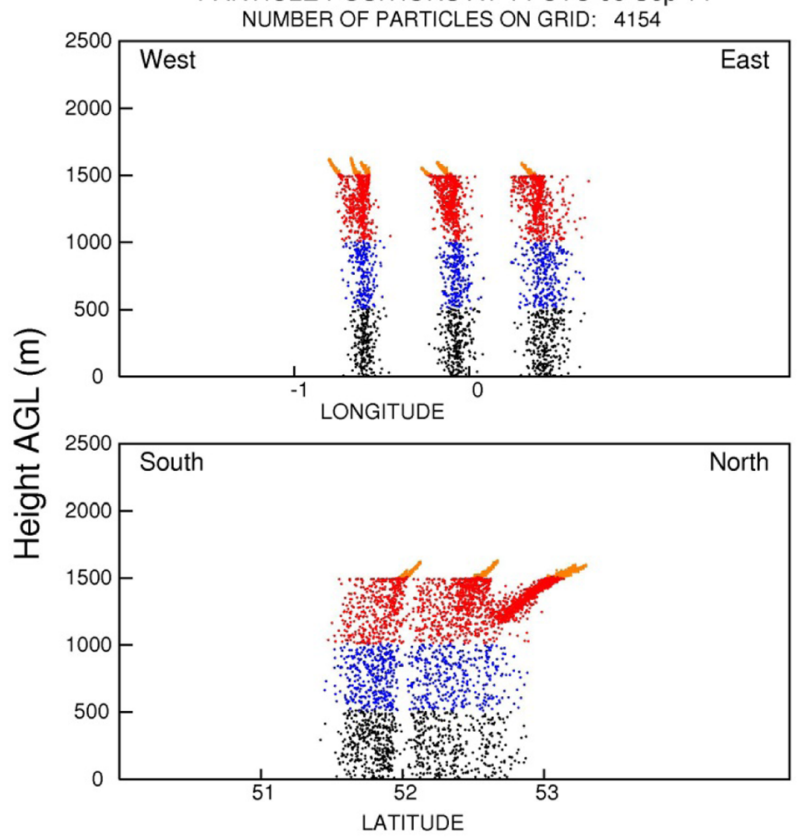

b INTEGRATED PARTICLE CROSS-SECTIONS PARTICLE POSITIONS AT 14 UTC 05 Sep 14
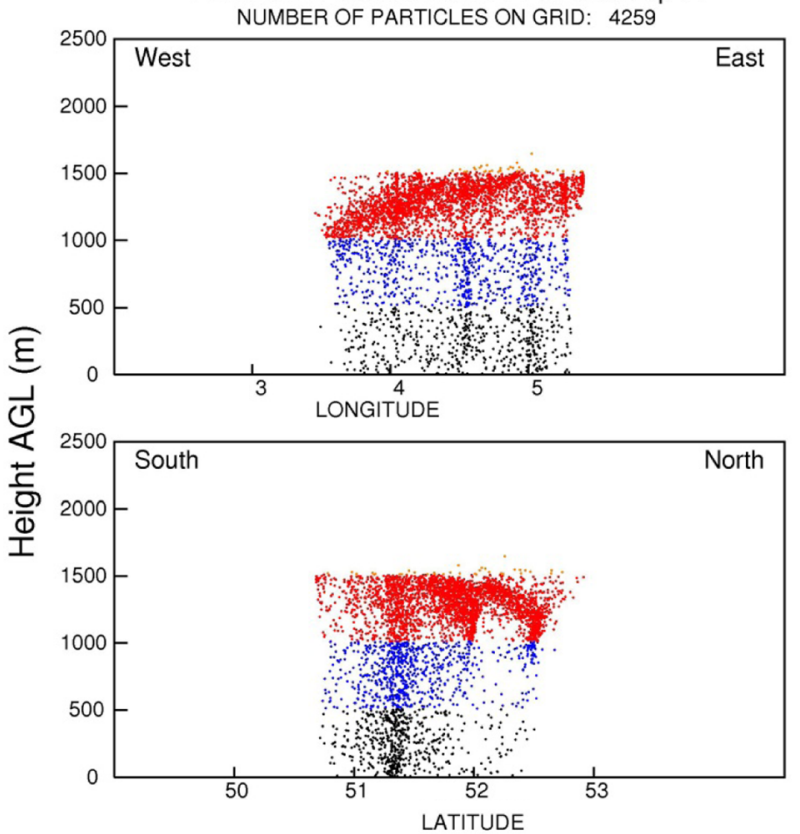

Fig. 6 The output of the HYSPLIT model calculations of the distribution of particles released from 6 to $14 \mathrm{~h}$ at the location air masses pass on 5 September 2014, $6 \mathrm{~h}$ before arrival to Leicester (a) and Leiden (b)

the findings relating to the Rhône Valley are uncertain due to limitations in resolving complex flows in this area.

It is not known whether such episodes of LDT have any consequences for the prevalence of sensitization to Ambrosia pollen. Threshold values required for Ambrosia pollen to induce symptoms differ among different studies, ranging from 1 to $3 \mathrm{P} \mathrm{m}^{-3}$ for "first symptoms to start" to $50 \mathrm{P} \mathrm{m}^{-3}$ for " $60-80 \%$ of the sensitized patients to show symptoms" (de Weger et al. 2012; Déchamp et al. 1997). The public Internet platform in the Netherlands (Allergieradar.nl), where sufferers can enter their symptom scores (de Weger et al. 2014), did not show increases in numbers of entries or symptom severity during the studied period. Although it is important to mention that the number of entries was very low during that period. Furthermore, it is a matter of debate whether pollen that have been exposed to extreme circumstances during LDT have preserved its allergenic capacity (Cecchi et al. 2010).

\section{Conclusion}

This study indicates that the Ambrosia pollen grains recorded at the beginning of September 2014 in Leicester and Leiden were probably not produced by local sources in response to range expansion due to climate change, but transported long distances from potential source regions in east Europe, i.e. the Pannonian Plain and Ukraine, as well as the Rhône Valley in France. As a result, this again confirms that Ambrosia pollen can be transported long distances from potential source regions, this time to the northwest fringes of Europe. In addition, we have shown that, using a dispersion model, Ambrosia pollen released from the Pannonian Plain reached high enough altitudes to enter westward-moving air masses and then settle out of the atmosphere to reach monitoring stations at ground level where they were recorded. This pollen released from the Pannonian Plain could augment the pollen moving west from more easterly areas such as Ukraine. The occurrence of an occluded front during the period helped to lift the pollen grains high into the atmosphere where they could be transported to northwest Europe. Furthermore, for the first time, we have identified the Rhône Valley in France as being a potential source of Ambrosia pollen in northwest Europe, albeit only a minor contributor compared to the Pannonian Plain. This study highlights the importance of the HYSPLIT dispersion model as a tool for distinguishing between LDT events and range expansion of an invasive, highly allergenic plant, an important distinction for plant and health management strategies.

Acknowledgments The results presented here address one of the scientific challenges described in the COST Action SMARTER. CHP is supported by the Midlands Asthma and Allergy Research Association (MAARA) and the National Institute for Health Research Leicester 
Respiratory Biomedical Research Unit. The views expressed are those of the author(s) and not necessarily those of the NHS, the NIHR or the Department of Health. BS is supported by OI and TR projects, financed by Ministry of Education, Science and Technological Development of Republic of Serbia.

\section{Compliance with ethical standards}

Conflict of interest The authors declare that they have no conflicts of interest.

Open Access This article is distributed under the terms of the Creative Commons Attribution 4.0 International License (http:// creativecommons.org/licenses/by/4.0/), which permits unrestricted use, distribution, and reproduction in any medium, provided you give appropriate credit to the original author(s) and the source, provide a link to the Creative Commons license, and indicate if changes were made.

\section{References}

Barnes C, Pacheco F, Landuyt J, Hu F, Portnoy J (2001) Hourly variation of airborne ragweed pollen in Kansas City. Ann Allergy Asthma Immunol 86:166-171

Belmonte J, Vendrell M, Roure J, Vidal J, Botey J, Cadahía A (2000) Levels of Ambrosia pollen in the atmospheric spectra of Catalan aerobiological stations. Aerobiologia 16:93-99

Beringen R, Odé B, and van Vliet AJH. (2014) Analyse trend en hotspots Alsemambrosia https://www.wageningenur.nl/nl/Publicatie-details. htm?publicationId=publication-way-343536373631 (visited 201502-17).

Bousquet PJ, Chinn S, Janson C, Kogevinas M, Burney P, Jarvis D (2007) Geographical variation in the prevalence of positive skin tests to environmental aeroallergens in the European Community Respiratory Health Survey I. Allergy 62:301-309

Cecchi L, Morabito M, Paola DM, Crisci A, Onorari M, Orlandini S (2006) Long distance transport of ragweed pollen as a potential cause of allergy in central Italy. Ann Allergy Asthma Immunol 96: $86-91$

Cecchi L, Testi S, Campi P, Orlandini S (2010) Long-distance transport of ragweed pollen does not induce new sensitizations in the short term. Aerobiologia 26:351-352

de Weger LA, van der Linden AC, Terreehorst I, van der Slikke WJ, van Vliet AJ, Hiemstra PS (2009) Ambrosia in the Netherlands. Allergic sensitisation and the distribution of plants and pollen. Ned Tijdschr Geneeskd 153:798-803

de Weger LA, Bergmann KC, Rantio-Lehtimäki A, Dahl A, Buters J, Déchamp C, Belmonte J, Thibaudon M, Cecchi L, Besancenot JP, Galán C, Waisel Y (2012) Impact of pollen. In: Sofiev M, KC B (eds) Allergenic pollen: a review of the production, release, distribution and health impacts. Springer, Dordrecht, pp. 161-216

de Weger LA, Hiemstra PS, Op den Buysch E, van Vliet AJ (2014) Spatiotemporal monitoring of allergic rhinitis symptoms in the Netherlands using citizen science. Allergy 69:1085-1091

Déchamp C, Rimet ML, Méon H, Deviller P (1997) Parameters of ragweed pollination in the Lyon's area (France) from 14 years of pollen counts. Aerobiologia 13:275-279

Draxler R, Stunder B, Rolph G, and Taylor A. 2009. HYSPLIT_4 user's guide: NOAA Air Resources Laboratory.

Essl F, Biró K, Brandes D, Broennimann O, Bullock JM, Chapman DS, Chauvel B, Dullinger S, Fumanal B, Guisan A, Karrer G, Kazinczi G, Kueffer C, Laitung B, Lavoie C, Leitner M, Mang T, Moser D, Müller-Schärer H, Petitpierre B, Richter R, Schaffner U, Smith M,
Starfinger U, Vautard R, Vogl G, von der Lippe M, Follak S (2015) Biological flora of the British Isles: Ambrosia artemisiifolia. J Ecol 104:1069-1098

Fernández-Llamazares Á, Belmonte J, Alarcón M, López-Pacheco M (2012) Ambrosia L. in Catalonia (NE Spain): expansion and aerobiology of a new bioinvader. Aerobiologia 28:435-451

Hamaoui-Laguel L, Vautard R, Liu L, Solmon F, Viovy N, Khvorostyanov D, Essl F, Chuine I, Colette A, Semenov MA, Schaffhauser A, Storkey J, Thibaudon M, Epstein MM (2015) Effects of climate change and seed dispersal on airborne ragweed pollen loads in Europe. Nat Clim Chang 5:766-771

Hernandez-Ceballos MA, Skjøth CA, Garcia-Mozo H, Bolivar JP, Galan C (2014) Improvement in the accuracy of back trajectories using WRF to identify pollen sources in southern Iberian Peninsula. Int $\mathbf{J}$ Biometeorol 58:2031-2043

Hirst JM (1952) An automatic volumetric spore trap. Ann Appl Biol 39: 257-265

Kasprzyk I, Myszkowska D, Grewling Ł, Stach A, Sikoparija B, Skjøth CA, Smith M (2011) The occurrence of Ambrosia pollen in Rzeszow, Krakow and Poznan, Poland: investigation of trends and possible transport of Ambrosia pollen from Ukraine. Int J Biometeorol 55:633-644

Makra L, Juhász M, Borsos E, Béczi R (2004) Meteorological variables connected with airborne ragweed pollen in Southern Hungary. Int J Biometeorol 49:37-47

Makra L, Sánta T, Matyasovszky I, Damialis A, Karatzas K, Bergmann KC, Vokou D (2010) Airborne pollen in three European cities: detection of atmospheric circulation pathways by applying threedimensional clustering of backward trajectories. J Geophys ResAtmos 115:D24220. doi:10.1029/2010JD014743

Martin MD, Chamecki M, Brush GS (2010) Anthesis synchronization and floral morphology determine diurnal patterns of ragweed pollen dispersal. Agric For Meteorol 150:1307-1317

Ogden EC, Hayes JV, Raynor GS (1969) Diurnal patterns of pollen emission in Ambrosia, Phleum, Zea, and Ricinus. Am J Bot 56:16-21

Oswalt M, Marshall G (2008) Ragweed as an example of worldwide allergen expansion. Allergy, Asthma Clin Immunol 4(3):1-6

Pashley CH, Satchwell J, Edwards RE (2015) Ragweed pollen: is climate change creating a new aeroallergen problem in the UK? Clin Exp Allergy 45:1262-1265

Podberezko I, Pylypenko L, Ya.Mar'uschkina V, Borzykh O (2013) Practical and economic efficacy of Ambrosia artemisiifolia L. surveillance in compliance with the international standards. J Plant Prot Res 53:392-398

Prank M, Chapman DS, Bullock JM, Belmonte J, Berger U, Dahl A, Jäger S, Kovtunenko I, Magyar D, Niemelä S, Rantio-Lehtimäki A, Rodinkova V, Saulienė I, Severova E, Sikoparija B, Sofiev M (2013) An operational model for forecasting ragweed pollen release and dispersion in Europe. Agric For Meteorol 182-183:43-53

Raynor GS, Ogden EC, Hayes JV (1970) Dispersion and deposition of ragweed pollen from experimental sources. J Appl Meteorol 9:885895

Reznik, S.Y. (2009) Common ragweed (Ambrosia artemisiifolia L.) in Russia: spread, distribution, abundance, harmfulness and control measures. Ambroisie, The first international ragweed review, 26. Available at: http://www.zin.ru/labs/expent/pdfs/Reznik_2009 Ambrosia.pdf

Saulienė I, Gudzinskas Z, Veriankaitė L, Malciute A, Lesciauskiene V (2011) Distribution of Ambrosia plants and airborne pollen in Lithuania. J Food Agric Environ 9:547-550

Šikoparija B, Smith M, Skjoth CA, Radišić P, Milkovska S, Šimić S, Brandt J (2009) The Pannonian plain as a source of Ambrosia pollen in the Balkans. Int J Biometeorol 53:263-72

Šikoparija B, Skjøth CA, Alm Kübler K, Dahl A, Sommer J, Grewling Ł, Radišić P, Smith M (2013) A mechanism for long distance transport 
of Ambrosia pollen from the Pannonian Plain. Agric For Meteorol 180:112-117

Skjøth AC, Hertel O, Ellermann T (2002) Use of the ACDEP trajectory model in the Danish nation-wide Background Monitoring Programme. Phys Chem Earth Pt B 27(35):1469-1477

Skjøth CA, Smith M, Sikoparija B, Stach A, Myszkowska D, Kasprzyk I, Radisic P, Stjepanovic B, rga I, Apatini D, Magyar D, Paldy A, Ianovici N (2010) A method for producing airborne pollen source inventories: an example of Ambrosia (ragweed) on the Pannonian Plain. Agric For Meteorol 150:1203-1210

Smith M, Skjøth CA, Myszkowska D, Uruska A, Puc M, Stach A, Balwierz K, Chlopek K, Piotrowskia K, Kasprzyk I, Brandt J (2008) Long-range transport of Ambrosia pollen to Poland. Agric For Meteorol 148:1402-1411

Smith M, Cecchi L, Skjoth CA, Karrer G, Sikoparija B (2013) Common ragweed: a threat to environmental health in Europe. Environ Int 61: $115-126$

Sommer J, Smith M, Kasprzyk I, Myszkowska D, Grewling L, Skjøth CA (2015) The risk of exposure to airborne Ambrosia pollen from local and distant sources in Europe - an example from Denmark. Am Acad Environ Med 22(4):625-631. doi:10.5604/12321966.1185764

Stach A, Smith M, Skjøth CA, Brandt J (2007) Examining Ambrosia pollen episodes at Poznan (Poland) using back-trajectory analysis. Int J Biometeorol 51:275-286

Starfinger U (2008) Zum Stand des Aktionsprogramms Ambrosia. The German action programme Ambrosia. Nachrichtenbl Deut Pflanzenschutz 60:201-204

Stohl A (1998) Computation, accuracy and applications of trajectories - a review and bibliography. Atmos Environ 32:947-966
Stohl A, Seibert P (1998) Accuracy of trajectories as determined from the conservation of meteorological tracers. Q J R Meteorol Soc 124: 1465-1484 Part: A

Storkey J, Stratonovitch P, Chapman DS, Vidotto F, Semenov MA (2014) A process-based approach to predicting the effect of climate change on the distribution of an invasive allergenic plant in Europe. PLoS One 9:e88156

Taramarcaz P, Lambelet B, Clot B, Keimer C, Hauser C (2005) Ragweed (Ambrosia) progression and its health risks: will Switzerland resist this invasion? Swiss Med Wkly 135:538-548

Thibaudon M, Hamberger C, Guilloux L, Massot R (2010) Ragweed pollen in France: origin, diffusion, exposure. Eur Ann Allergy Clin Immunol 42:209-215

Thibaudon M, Sikoparija B, Onorari M, Smith M, Skjoth CA (2014) Ragweed pollen source inventory for France - the second largest centre of Ambrosia in Europe. Atmos Environ 83:62-71

Tosi A, Wuthrich B, Bonini M, Pietragalla-Kohler B (2011) Time lag between Ambrosia sensitisation and Ambrosia allergy: a 20-year study (1989-2008) in Legnano, northern Italy. Swiss Med Wkly. doi:10.4414/smw.2011.13253

Zemmer F, Karaca F, Ozkaragoz F (2012) Ragweed pollen observed in Turkey: detection of sources using back trajectory models. Sci Total Environ 430:101-108

Zheng T, Yu J, Oh MH, Zhu Z (2011) The atopic march: progression from atopic dermatitis to allergic rhinitis and asthma. Allergy, Asthma Immunol Res 3:67-73

Klein Tank A, Beersma J, Bessembinde J, van den Hurk B, en Lenderink G (2014) Klimaatscenrios voor Nederland KNMI '14. http://www. klimaatscenarios.n1/images/Brochure_KNMI14_NL.pdf 